\title{
JOURNAL OF THE AMERICAN GERIATRIC SOCIETY
}

\section{TITLE PAGE}

TITLE: Caregiver interventions for adults discharged from hospital: systematic review \& metaanalysis

RUNNING TITLE: Caregiver training hospitalized adults

Authors: Toby O Smith $\mathrm{PhD}^{1}$, Matthew Pearson MSc${ }^{2}$, Klaus Pfeiffer $\mathrm{PhD}^{3}$, Maria Crotty $\mathrm{PhD}^{4}$, Sallie E Lamb DPhil ${ }^{1}$

\section{Affiliations:}

1. Nuffield Department of Orthopaedics, Rheumatology and Musculoskeletal Sciences, University of Oxford, Oxford, UK

2. Physiotherapy Outpatients Department, Dynamic Health, Cambridgeshire Community Services NHS Trust, Huntingdon, UK

3. Department of Clinical Gerontology and Rehabilitation, Robert-Bosch-Hospital, Stuttgart, Germany

4. Flinders Medical Centre, Flinders University, Adelaide, Australia

Corresponding Author: Dr Toby Smith, Nuffield Department of Orthopaedics, Rheumatology and Musculoskeletal Sciences, Botnar Research Centre, Nuffield Orthopaedic Centre, Windmill Road Oxford, OX3 7LD, UK. Email: toby.smith@ndorms.ox.ac.uk; Twitter: @tobyosmith

Word Count - Abstract: 248

Word Count - Text: 3538

Number of Figures - 2

Number of Tables - 2 


\section{ABSTRACT}

OBJECTIVES: To review the evidence evaluating the effectiveness of informal caregiver interventions to facilitate the recovery of older people discharged from hospital.

METHODS: Published and unpublished randomised and non-randomised controlled trials assessing the effectiveness of informal caregiver interventions to support the recovery of older people discharged from hospital, were identified (to March 2019). The primary outcome was patient healthrelated quality of life (HRQOL). Secondary outcomes included: patient function, caregiver burden, carer HRQOL, psychological distress, adverse events and health resource use. Studies were critically appraised and meta-analysed.

PARTICIPANTS: Adults who had been admitted to hospital.

RESULTS: 23 studies were eligible (4695 participants). The indication for hospital admission was stroke in 21 trials (91\%). Interventions consisted of training and/or skills-based programmes, with or without home visits/telephone follow-up. Caregiver interventions for patients following stroke may provide no benefit for patient HRQOL at 12 months (standardised mean difference (SMD): 0.29; 95\% confidence intervals $(\mathrm{Cl})$ : -0.12 to 0.69 ; low quality evidence). Caregiver interventions demonstrated benefit for caregiver burden, patient and caregiver anxiety at 12 months. There was no consistent effect on functional outcomes, depression, $\mathrm{HRQOL}$, adverse events or health resource use measures.

CONCLUSIONS: Informal carers who receive training to facilitate the recovery of older people discharged from hospital following stroke may have lower burden, and reduced anxiety at 12 months compared to those who do not. However, the evidence was moderate to low quality. Further study is warranted to explore whether caregiver interventions can be modified for non-stroke populations such as hip fracture.

Keywords: informal carer; education; training; hospital discharge; rehabilitation 


\section{INTRODUCTION}

Life expectancy for people in industrialized countries, including the USA, is increasing. ${ }^{1}$ Between 2000 and 2050 , the proportion of the world's population aged over 60 years will double from $11 \%$ to $22 \%{ }^{2}$ An ageing population brings increasing challenges for health and social services.

Older people discharged from hospital to the community are at risk of declining physical and mental health. ${ }^{3}$ Family members and friends are often expected to support the transition from hospital to home, facilitating on-going recovery. ${ }^{4}$ Qualitative evidence suggests that informal caregivers feel under-skilled and lack confidence to provide this support. ${ }^{5}$ This can lead to increased stress within the patient-carer dyad. ${ }^{5}$ Several authors have hypothesised that providing training to informal caregivers prior to patient hospital discharge may reduce stress and improve recovery. ${ }^{6-8}$ Teaching caregiver skills to better support patients following hospital admission may improve quality of life and independence and reduce the burden of impairment for patients but also caregivers. ${ }^{9,10}$ Events such as falls and postoperative complications could be reduced, thereby reducing burden on health and care services. ${ }^{9,10}$ These interventions may act to establish a stable care routine for longer-term re-enablement, to promote independence for individuals following hospital admission. Through increased independence and better caregiver support, paid community care or institutionalization may be reduced or prevented. ${ }^{11}$

Previous literature has explored interventions aimed at training informal caregivers of older people with chronic conditions, most notably dementia. ${ }^{12-15}$ These have centred on interventions for longerterm maintenance of health rather than training on the transition from hospital to home. No systematic reviews have assessed the effect of caregiver interventions on patient recovery to improve health outcomes following hospital discharge. This systematic review aimed to address this limitation and determine the effectiveness of training interventions for informal caregivers of older people to support recovery after hospital discharge.

\section{METHODS}

This systematic review was registered through the International Prospective Register of Systematic Reviews database (PROSPERO: CRD42018102659) and followed the Preferred Reporting Items for Systematic review and Meta-Analysis (PRISMA) guidelines. ${ }^{16}$ 


\section{Search Strategy}

The search was undertaken on $2^{\text {nd }}$ August 2018 and updated on $20^{\text {th }}$ March 2019 by one reviewer (TS) using published and unpublished literature databases including EMBASE, MEDLINE, CINAHL and PubMed. The search strategy for EMBASE is presented in Supplementary Table 1, and was modified for each database. We accessed clinical trial registries for unpublished or ongoing clinical trials including the WHO International Clinical Trial Registry and ClinicalTrials.gov registry. Reference lists of all potentially eligible studies were reviewed by two reviewers (TS, MP) and all corresponding authors from included studies were contacted to identify other studies.

\section{Selection Criteria}

\section{Inclusion criteria:}

- Studies recruiting adults discharged from hospital (acute or rehabilitation settings), who had access to an informal caregiver. Informal caregiver was defined as a person who provides unpaid support to a friend or relative for assistance with medical needs and/or disability.

- Training interventions which aimed to support recovery and commenced in an in-patient setting or within 30 days of hospital discharge. Interventions were required to provide some form of training to facilitate recovery following hospital admission. Training was defined as providing caregivers information (face-to-face or telephone/online) with or without physical skills in activities such as facilitating manual handling and assistance with activities of daily living (ADL). This may have included supplementary interventions including follow-up telephone calls/video messaging, online resources and/or paper-based reading materials.

- Studies which reported one or more of the following outcomes: caregiver burden, patient or caregiver health-related quality of life (HRQOL), patient function, patient or caregiver anxiety or depression, adverse events, cost-effectiveness or health resource use.

\section{Exclusion criteria:}

- Participants admitted following a mental health episode.

- Interventions delivered as part of an end of life or palliative care programme.

- Interventions which were solely designed to facilitate discharge planning e.g. telephone support services, providing no caregiver training element. 
Two reviewers (TS,MP) independently reviewed all titles and abstracts from the search results. Fulltext papers for all potentially eligible studies were independently reviewed by each reviewer (TS, MP) to determine final inclusion. Disagreements between the two reviewers were resolved through discussion, with an adjudicator (SL) available to address any disagreements.

\section{Data Extraction}

Data were extracted onto a pre-defined data extraction form by one reviewer (TS) and verified by a second (MP). Where the same study was reported across two or more papers, these were classified as a single study to avoid multiple counting.

Data extracted included: country of origin, year of study conduct, number and characteristics of participants including data on: age, gender, medical morbidities, reason for hospital admission, characteristics of informal caregivers e.g. age, gender, whether in paid work, medical status, relationship status to the patient, treatment strategies provided, timing of data collection from acute or rehabilitation hospital discharge, and outcomes for the intervention versus control groups.

Disagreements in data extraction between the reviewers, particularly on intervention content and trial results, were resolved through discussion to gain agreement.

\section{Outcome Measures and End-Points}

The primary outcome measure was patient HRQOL. This is justified given the reported importance of patient $\mathrm{HRQOL}$ as a meaningful outcome shared by both patient and caregiver. ${ }^{17}$ Secondary outcome measures included: caregiver $\mathrm{HRQOL}$, caregiver burden, patient function, patient and caregiver anxiety and depression, adverse events (including falls, delirium, medical complications, delayed hospital discharge and emergency department/hospital re-admission) and cost-effectiveness/health resource utilisation. These diverse outcome domains were warranted to ensure that both patient and caregiver outcomes were measured, acknowledging the complex social and health needs which this dyad present. ${ }^{18}$

The primary end-point was 12 months (long-term outcome). Outcomes were also analysed as shortterm (zero to 90-days after hospital discharge), or mid-term (three to six months after hospital discharge). 


\section{Assessment of Methodological Quality of Studies Included for Review}

Two reviewers (TS, MP) independently critically appraised each included study using the Cochrane Risk of Bias tool for randomised controlled trials (RCTs) ${ }^{19}$ and the Downs and Black checklist for nonRCTs. ${ }^{20}$ Disagreements in scoring between the reviewers were resolved through discussion.

\section{Data Analysis}

Data extraction tables were reviewed for study heterogeneity by two reviewers (TS, MP). Through this, between-study variability in participant characteristics (patients and caregivers), interventions and study design were assessed. Where heterogeneous, a narrative analysis of the results was presented. Where homogeneous, data were pooled for those outcomes using a Mantel-Haenszel method meta-analysis. ${ }^{21}$ For continuous outcomes, when trials used the same outcome instrument to assess an outcome domain, mean difference (MD) and 95\% confidence intervals (CI) were presented. When trials used different outcome instruments for an outcome domain, standardized mean difference (SMD) and 95\% Cls were reported. For dichotomous outcomes, risk ratios (RR) and 95\% Cls were presented. For each meta-analysis, statistical heterogeneity was assessed using the $\mathrm{I}^{2}$ statistic. Where $I^{2}$ was greater or equal to $40 \%$, data were reported using random-effect models. When less than $40 \%$, data were reported using fixed-effect models. ${ }^{21}$ Two corresponding authors were contacted to gain clarification on missing data. ${ }^{22,23}$

Small sample size publication was assessed using funnel plots, provided there were a minimum of 10 studies for each outcome. ${ }^{19}$

Sensitivity analyses were undertaken by removing studies with both: high risk of bias for detection bias and which did not present an a priori sample size calculation.

Planned subgroup analyses were:

(A) Timing of the training intervention (i.e. before hospital discharge vs. after hospital discharge).

(B) Type of training intervention (i.e. physical skills-based vs. advice-based).

All analyses were conducted by one reviewer (TS) using RevMan (Review Manager (RevMan) [Computer program]. Version 5.3. Copenhagen: The Nordic Cochrane Centre, The Cochrane Collaboration, 2014.) 


\section{Assessment of GRADE}

We assessed the quality of evidence for each outcome using the Grading of Recommendations, Assessment, Development and Evaluation (GRADE) criteria. ${ }^{24}$ Through this, two reviewers (TS, MP) assessed outcomes by: (1) methodological limitations through the assessment of risk of bias using the Cochrane Risk of Bias and Down and Black tools; (2) indirectness relating to similarity to clinical practice; (3) imprecision relating to the number of participants and events; (4) inconsistency in effect estimates across the studies for a given analysis; and (5) likelihood of publication bias. ${ }^{24}$

\section{RESULTS}

\section{Literature Search}

The results of the search strategy are summarised in Figure 1. In total, 3268 citations (2492 with duplicates removed) were identified. Of these, 23 studies (28 papers) met the eligibility criteria and were included. Five studies reported results across two papers. This included 21 randomised controlled trials ${ }^{22,23,25-43}$ and two non-randomised controlled studies. ${ }^{44,45}$ All papers were reported in English.

\section{Methodological Quality of Studies Included for Review}

Twenty-one trials were appraised (Supplementary Table 2). In summary, whilst there was low risk of bias for random sequence generation, six trials $(6 / 21 ; 29 \%)$ presented with high risk of selection bias by not concealing allocation during randomisation. ${ }^{25-30}$ All included trials demonstrated high risk of bias for performance bias as it is logistically not possible to blind participants to these interventions. However, seven trials $(7 / 21 ; 33 \%)$ also demonstrated detection bias. ${ }^{23,25,27,28,31-33}$ Ten trials (10/21; $52 \%)$ demonstrated attrition bias. ${ }^{22,26-28,30,32-36}$ Major additional sources of bias were the risk of baseline imbalance $(4 / 21 ; 19 \%), 22,26,34,37$ not clearly reporting intervention fidelity $(2 / 21 ; 10 \%),{ }^{31,38}$ risk that participants did not receive allocated interventions $(1 / 21 ; 5 \%),{ }^{31}$ whilst two studies did not base their sample sizes on a priori sample size calculations $(2 / 21 ; 10 \%) .25,28$

The results from the Downs and Black checklist appraisal for the remaining two studies ${ }^{44,45}$ are presented in Supplementary Table 3. There were recurrent limitations around internal validity, particularly around blinding and intervention compliance. Both studies were judged as underpowered. 


\section{Publication Bias}

There were sufficient data to construct a funnel plot for the outcome 'patient functional outcomes' (three to six months) (Supplementary Figure 1). This indicated moderate risk of small sample size publication bias.

\section{Characteristics of Participants of Included Studies}

A summary of the 23 included studies is presented in Table 1. This included 4695 patient participants; 2271 randomised to the caregiver interventions, 2350 to the control interventions. One study ${ }^{40}$ did not report the numbers of participants randomised to their groups amongst their 74 participants.

Trials were published between $2000^{37}$ and $2017 .{ }^{39}$ Seven studies were conducted in the USA, $, 26,27,33-$ $35,40,41$ three in Australia, ${ }^{29,31,36}$ three in the UK, ${ }^{23,42,43}$ two in Taiwan, ${ }^{28,30}$ and individual studies from Canada, ${ }^{38}$ Sweden, ${ }^{32}$ Ireland, ${ }^{22}$ Germany, ${ }^{26}$ India, ${ }^{39}$ Spain ${ }^{44}$ and Thailand ${ }^{45}$

The mean age of patient participants was reported in 21 trials, ranging from 57 years ${ }^{38}$ to 86 years. ${ }^{44}$ Fifteen studies reported the mean age for caregivers. This ranged from 44 years ${ }^{45}$ to 70 years. ${ }^{31}$ Clinical populations under-investigation were stroke survivors and their caregivers in 21 studies (21/23; 91\%). ${ }^{16-19,21-36,3823,25-43,45}$ Two studies investigated older people admitted to hospital, irrespective of medical diagnosis. ${ }^{29,44}$ The mean duration of hospital admission was reported in seven studies. ${ }^{22,23,26,28,31,35,43}$ This ranged from nine days ${ }^{35}$ to 64 days. $^{25}$

\section{Intervention Characteristics}

Interventions largely consisted of training provided through a variety of formats, with or without follow-up contact (Supplementary Table 4). Training was delivered before hospital discharge in 16 studies(16/23; 70\%), 22,23,25-27,29-31,35,36,38,41-45 and within the first three-months after discharge in six (6/23; 26\%). ${ }^{25,32,33,34,37,40}$ Eight studies $(8 / 23 ; 35 \%)$ provided after discharge home-visits to monitor progress and provide ongoing support. $23,26,28,29,37,39,41,42$ Visits ranged in frequency from one ${ }^{37}$ to an average of 16 visits. ${ }^{41}$ Eight studies (35\%) provided a supplementary follow-up telephone call, ${ }^{27,28,29,34,35,38,40,45}$ ranging in frequency from one ${ }^{28}$ to 13 calls..$^{35}$ Twenty studies reported the professional-backgrounds of healthcare providers who delivered training interventions. This was a nurse in seven trials, ${ }^{25,28,29,32,34,40,45}$ members of the multidisciplinary team in five trials, ${ }^{26,23,33,42,43}$ a physical therapist in four trials, ${ }^{22,30,41,44}$, and a social worker, ${ }^{31}$ and a stroke family support organiser ${ }^{37}$ 
in one trial each. Three trials did not state the professional backgrounds of their intervention deliverers. ${ }^{27,35,38}$

The location where caregiver interventions were delivered was reported in all trials. This started in hospital and continued a home in 14 trials, $22,25-28,30,31,35,36-39,41,42$ four trials delivered their caregiver interventions solely in patient's homes, ${ }^{29,33,34,40}$ three trial interventions were delivered solely in hospitals, ${ }^{43-45}$ whilst two trials reported that their caregiver interventions were delivered either in hospital or in patient's homes depending on whether they had been discharged or not by a specific time-point. 22,32

Key intervention components included problem-solving $(3 / 23 ; 13 \%),{ }^{34,36,43}$ goal-setting $(3 / 23$; $13 \%),{ }^{29,39,43}$ and training on preventing future admissions and after hospital complications (7/23; $30 \%$ ). $27,29,31,32,37,42,45$ Seven studies $(7 / 23 ; 30 \%)$ included elements of skill-based activities where caregivers were taught handling skills. ${ }^{22,23,25,26,39,42,45}$ However, these skills were largely to improve transfers (e.g. bed to chair movement), mobility and personal ADLs (e.g. washing, dressing).

\section{Meta-Analysis Outcomes}

\section{Primary Outcome Measure: Patient HRQOL}

Three studies reported patient HRQOL at 12 months $28,32,42$ and five studies at three to six months after randomisation. 28,32,36,39,42 All patients had experienced a stroke.

There was no benefit in patient HRQOL for those randomised to the caregiver intervention compared to the control at 12 months (SMD: $0.29 ; 95 \% \mathrm{Cl}:-0.12$ to $0.69 ; \mathrm{N}=500 ; I^{2}: 79 \%$; Figure 2). However, on the sensitivity analysis, those randomised to the caregiver intervention reported increased HRQOL compared to the control group (MD: $6.00 ; 95 \% \mathrm{Cl}: 3.68$ to 8.32; N=257; $I^{2}$ : Not Estimated (NE) as single study). There was no between-group difference at three to six months (SMD: $-0.08 ; 95 \% \mathrm{Cl}:-0.18$ to $0.02 ; \mathrm{N}=1624 ; I^{2}: 0 \%$; Figure 2). This was also reported by the sensitivity analysis (Table 2 ).

These outcomes were classified as low-quality evidence due to serious risk of bias and imprecision. 


\section{Secondary Outcome Measures}

\section{Caregiver $H R Q O L$}

Two studies reported caregiver HRQOL at 12 months $^{28,42}$ and four studies at three to six months after randomisation. ${ }^{28,42,43,45}$ All patients had experienced a stroke.

There was no benefit from the caregiver intervention on caregiver HRQOL compared to the control group at 12 months (SMD: $0.46 ; 95 \% \mathrm{Cl}:-0.34$ to $1.27 ; \mathrm{N}=415 ; \mathrm{I}^{2}: 94 \%$ ). This remained the same in the sensitivity analysis. Similarly, there was no between-group difference at the three to six-month assessment of caregiver HRQOL on the principal meta-analysis (SMD: 0.20; 95\% Cl: -1.12 to 1.52; $\mathrm{N}=638 ; I^{2}: 98 \%$ ) or sensitivity analysis (Table 2 ).

These outcomes were classified as low-quality evidence on the GRADE assessment due to serious risk of bias and imprecision.

\section{Caregiver Burden}

Only one trial ${ }^{42}$ reported caregiver burden at 12 months. This reported a lowering of caregiver burden (SMD: $-2.21 ; 95 \% \mathrm{Cl}:-2.51$ to $-1.92 ; \mathrm{N}=283 ; \mathrm{I}^{2}$ : NE as single study). On GRADE assessment, we identified a serious risk of bias, and classed this as moderate evidence.

Nine studies, all recruiting patients who had experienced a stroke, reported caregiver burden at three to six months. $22,23,25,26,30,36,39,42,45$ There was no significant between-group difference for this outcome at this time-point (SMD: $-0.33 ; 95 \% \mathrm{Cl}:-0.71$ to $0.04 ; \mathrm{N}=1823 ; \mathrm{I}^{2}$ : $94 \%$ ). This was also reported by the sensitivity analysis (Table 2). On GRADE assessment, we identified a serious risk of bias, and classed this as moderate evidence. This outcome was classified as low-quality evidence due to risk of bias and inconsistency.

\section{Patient Function}

Four studies reported patient function at 12 months ${ }^{26,28,32,41}$ and ten studies at three to six months after randomisation..$^{22,23,25,28,30-32,39,43,45}$ All patients had experienced a stroke.

There was no between-group difference in functional outcomes for caregiver interventions at 12 months (SMD: $-0.02 ; 95 \% \mathrm{Cl}:-0.17$ to $0.13 ; \mathrm{N}=677 ; \mathrm{I}^{2}: 42 \%$ ) or three to six months (SMD: $0.00 ; 95 \% \mathrm{Cl}$ : 
-0.08 to $0.08 ; \mathrm{N}=2449 ; I^{2}: 46 \%$ ). This was also reported by the sensitivity analyses (Table 2 ). There was no difference in outcomes on subgroup analysis when only skills-based caregiver interventions were assessed as opposed to advice-based ( 12 month: SMD: $0.10 ; 95 \% \mathrm{Cl}:-0.27$ to $0.07 ; \mathrm{N}=526 ; \mathrm{I}^{2}: 0 \%$; three to six months: SMD: $0.05 ; 95 \% \mathrm{Cl}:-0.16$ to $0.05 ; \mathrm{N}=1312 ; \mathrm{I}^{2}$ : $\left.59 \%\right)$.

On GRADE assessment, we identified a serious risk of bias and inconsistency, and classed this as lowquality evidence.

\section{Patient Psychological Distress}

Two studies reported patient psychological distress at 12 months ${ }^{26,42}$ and six studies at three to six months after randomisation. ${ }^{26,31,36,39,42,43}$ All patients had experienced a stroke.

Patients who received the caregiver interventions reported reduced anxiety at 12 months compared to those randomised to the control group (MD: $-1.75 ; 95 \% \mathrm{Cl}:-1.89$ to $-1.61 ; \mathrm{N}=300 ; \mathrm{I}^{2}$ : NE as single study). However, there was no between-group difference at three to six months on the principal metaanalysis (SMD: $-0.69 ; 95 \% \mathrm{Cl}:-1.79$ to $0.41 ; \mathrm{N}=1610 ; \mathrm{I}^{2}$ : 99\%). This was also reported by the sensitivity analysis.

There was no benefit from the caregiver intervention on patient depression compared to the control group at 12 months (SMD: $-0.33 ; 95 \% \mathrm{Cl}:-1.71$ to $1.05 ; \mathrm{N}=434 ; \mathrm{I}^{2}: 98 \%$ ) and three to six months (SMD: $-0.15 ; 95 \% \mathrm{Cl}:-0.63$ to $\left.0.33 ; \mathrm{N}=1682 ; I^{2}: 94 \%\right)$. This was also reported by the sensitivity analysis (Table 2).

These outcomes were classified as low-quality evidence on the GRADE assessment due to serious risk of bias and inconsistency.

\section{Caregiver Psychological Distress}

Caregiver psychological distress was assessed at 12 months in four studies $26,28,32,42$ and at three to six months in six studies. ${ }^{25,26,28,31,32,39}$ All patients had experienced a stroke.

Single studies reported caregiver anxiety. Kalra et $\mathrm{al}^{42}$ reported that caregivers randomised to a caregiver intervention reported significantly lower anxiety compared to a usual care control at 12 months (MD: $-1.25 ; 95 \% \mathrm{Cl}:-1.43$ to $-1.07 ; \mathrm{N}=284 ; \mathrm{I}^{2}$ : NE). However, Lindsey et a ${ }^{39}$ reported no benefit to caregiver interventions on caregiver anxiety at three to six months (MD: 0.10; $95 \% \mathrm{Cl}:-0.32$ to 0.52 ; $\left.N=1043 ; I^{2}: N E\right)$. 
There was no benefit from the caregiver intervention on caregiver depression compared to the control group at three to six months (SMD: $0.03 ; 95 \% \mathrm{Cl}:-0.08$ to $0.14 ; \mathrm{N}=1239 ; I^{2}: 0 \%$ ) or 12 months (SMD: $0.71 ; 95 \% \mathrm{Cl}:-2.23$ to $0.81 ; \mathrm{N}=613 ; \mathrm{I}^{2}$ : $99 \%$ ). This was also reported by the sensitivity analyses (Table 2).

Both caregiver anxiety and depression outcomes were classified as low-quality evidence due to serious risk of bias and inconsistency.

\section{Adverse Events}

Five studies reported adverse events, ${ }^{25,39,42-44}$ and two reported rehospitalization. ${ }^{39,41}$ There was no benefit from caregiver interventions for mortality, rehospitalization or adverse events at 12 months. These were classified as very low-quality evidence due to serious risk of bias, inconsistency and imprecision. This did not differ on the sensitivity analyses (Table 2).

\section{Cost-Effectiveness/Health Resource Utilisation Data}

Hospital length of stay was reported in three studies. ${ }^{39,41,43}$ Two studies assessed out-patient services, ${ }^{25,43}$ whilst two reported institutionalization. ${ }^{33,42}$ All patients had experienced a stroke. There was no significant difference in either hospital length of stay (MD: $-0.22 ; 95 \% \mathrm{Cl}:-0.97$ to $0.53 ; \mathrm{N}=1484$; $I^{2}: 20 \%$ ) or institutionalisation when assessed at three to six months (RR: $0.44 ; 95 \% \mathrm{Cl}: 0.14$ to 1.39; $\mathrm{N}=300$; $1^{2}: \mathrm{NE}$ ) or 12 months (RR: 0.37; $95 \mathrm{Cl}: 0.10$ to 1.39; N=373; $I^{2}: \mathrm{NE}$ ). However, participants randomised to caregiver interventions were more likely to access out-patient services within the initial six months after discharge compared to the control group (RR: $1.88 ; 95 \% \mathrm{Cl}: 1.07,3.29 ; \mathrm{N}=187: \mathrm{I}^{2}: 0 \%$ ). These outcomes did not differ on the sensitivity analyses (Table 2).

On the GRADE assessment, this outcome was classified as very low-quality evidence due to inconsistency, imprecision and serious risk of bias.

\section{DISCUSSION}

For patient following stroke, interventions to train informal caregivers may decrease patient and caregiver anxiety and reduce caregiver burden at 12 months post-hospital admission. The evidence suggests that these interventions may not affect functional outcomes. The evidence was moderate 
to low-quality and should be viewed with caution. The current evidence is largely based on trials recruiting stroke survivors. The composition and effectiveness of caregiver interventions for nonstroke populations remains uncertain.

Both patient and caregiver anxiety may be reduced through caregiver training interventions. The effect was smaller and not significant at three to six months compared to 12 months. The 12 -month data were based on one study. ${ }^{42}$ This suggests that the interventions had a more prolonged treatment effects which may reflect a longer recovery trajectory following stroke. ${ }^{46}$ It may also reflect a difference in 'priorities' experienced by patients after stroke, which the interventions may not target during the initial months following discharge. ${ }^{47,48}$

Caregiver interventions may not affect functional recovery. This may be attributed to two factors. Firstly, interventions were largely designed to increase knowledge. Only seven studies (29\%) included interventions targeting physical training/activity promotion to improve function. ${ }^{25,26,22,23,39,42,45}$ Secondly, included studies predominantly recruited stroke survivors. It remains unclear whether functional gains, would be greater for those who experience disability from other causes such as hip fracture or falls, with different recovery trajectories compared to stroke survivors. ${ }^{46,49}$ Further consideration on the functional components of caregiver interventions, is warranted.

No studies recruited patients with cognitive impairment. This was surprising given previous caregiver interventions have been developed forcaregivers of people with dementia who live within the community. ${ }^{50-52}$ As people with dementia often experience worse functional outcome after hospitalization, ${ }^{53}$ developing and testing such an interventions is a priority.

Patient HRQOL was greater when interventions were delivered pre-discharge rather than posthospital discharge. This may be because interventions were largely 'knowledge-based' rather than 'skills-based'. Timing of intervention may therefore be related to the composition of the intervention and its mode of delivery. Consideration on intervention timing and provision pre-discharge to prepare informal caregivers for early, active engagement in post-discharge recovery, should be considered. 
To conclude, the addition of caregiver interventions may reduce caregiver burden and caregiver and patient anxiety within the first 12 months following hospital discharge. The evidence suggests that current caregiver interventions may not affect functional outcomes. The current evidence is largely based on trials recruiting stroke survivors. Further study is warranted to explore whether caregiver interventions can be modified for non-stroke populations such as hip fracture. Modification of the intervention to provide greater handling and skills-based knowledge and experiential learning for informal carers prior to hospital discharge, may provide the opportunity to enhance HRQOL whilst reducing psychological distress associated with the transition from hospital to home. 


\section{ACKNOWLEDGEMENTS}

Dr Smith and Professor Lamb are supported by funding from the National Institute for Health Research (NIHR) Oxford Health Biomedical Research Centre. The views expressed are those of the author(s) and not necessarily those of the NIHR.

The authors would like to express their gratitude and thanks to all those authors who responded to study queries and data requests.

Conflict of Interest: All authors have declared no conflicts of interest for this article.

Funding: No funding was received to undertake the conduct of this study.

Ethical approval: No ethical approval was required for this study design.

Author Contributions: The research question, concept and design were formulated by Toby Smith, Klaus Pfeiffer, Maria Crotty and Sallie Lamb. The trial selection was completed by: Toby Smith and Matthew Pearson. Data analysis was completed by Toby Smith and Sallie Lamb. Preparation of the manuscript was completed by Toby Smith, Klaus Pfeiffer, Maria Crotty and Sallie Lamb. Approval of the final version of the manuscript was from Toby Smith, Klaus Pfeiffer, Maria Crotty and Sallie Lamb.

Sponsor's Role: None 


\section{REFERENCES}

1. Kontis V, Bennett JE, Mathers CD, Li G, Foreman K, Ezzati M. Future life expectancy in 35 industrialised countries: projections with a Bayesian model ensemble. Lancet 2017;389:1323-1335.

2. World Health Organisation. Ageing and Life-Course. Accessed 25 April 2018. Available at: http://www.who.int/ageing/about/ageing life course/en/

3. Lawler K, Taylor NF, Shields N.

Involving family members in physiotherapy for older people transitioning from hospital to the community: a qualitative analysis. Disabil Rehabil 2015;37:2061-2069.

4. Ariza-Vega P, Ortiz-Piña M, Kristensen MT, Castellote-Caballero Y, Jiménez-Moleón JJ. High perceived caregiver burden for relatives of patients following hip fracture surgery. Disabil Rehabil 2019;41:311-318.

5. Saletti-Cuesta L, Tutton E, Langstaff D, Willett K. Understanding informal carers' experiences of caring for older people with a hip fracture: a systematic review of qualitative studies. Disabil Rehabil 2018;40:740-750.

6. Quinn C, Jones IR, Martyr A, Nelis SM, Morris RG, Clare L. Caregivers' beliefs about dementia: findings from the IDEAL study. Psychol Health 2019:In Press.

7. Yoo R, Yeom J, Kim GH, Park HK, Kang Y, Hwang J, Choi SH, Na HR, Cho SJ, Yu KH, Kim DH, Lee $\mathrm{JH}$, Jeong JH. A multicenter, randomized clinical trial to assess the efficacy of a therapeutic intervention program for caregivers of people with dementia. J Clin Neurol 2019;15:235-242.

8. Clarkson P, Davies L, Jasper R, Loynes N, Challis D. Home Support in Dementia (HoSt-D) Programme Management Group. A systematic review of the economic evidence for home support interventions in dementia. Value Health 2017;20:1198-1209.

9. Baillie L, Gallini A, Corser R, Elworthy G, Scotcher A, Barrand A. Care transitions for frail, older people from acute hospital wards within an integrated healthcare system in England: a qualitative case study. Int J Integr Care 2014;14:e009.

10. Giosa JL, Stolee P, Dupuis SL, Mock SE, Santi SM. Examination of family caregiver experiences during care transitions of older adults. Can J Aging 2014;33:137-153.

11. Betini RSD, Hirdes JP, Lero DS, Cadell S, Poss J, Heckman G. A longitudinal study looking at and beyond care recipient health as a predictor of long term care home admission. BMC Health Serv Res 2017;17:709.

12. Chi NC, Demiris G. A systematic review of telehealth tools and interventions to support family caregivers. J Telemed Telecare 2015;21:37-44.

13. Zabalegui A, Hamers JP, Karlsson S, Leino-Kilpi H, Renom-Guiteras A, Saks K, Soto M, Sutcliffe $C$, Cabrera E. Best practices interventions to improve quality of care of people with dementia living at home. Patient Educ Couns 2014;95:175-184.

14. Moon H, Adams KB. The effectiveness of dyadic interventions for people with dementia and their caregivers. Dementia 2013;12:821-839. 
15. Aldehaim AY, Alotaibi FF, Uphold CR, Dang S. The impact of technology-based interventions on informal caregivers of stroke survivors: a systematic review. Telemed J E-health 2016;22:223-231.

16. Moher D, Liberati A, Tetzlaff J, Altman DG; PRISMA Group. Preferred reporting items for systematic reviews and meta-analyses: the PRISMA statement. J Clin Epidemiol 2009;62:1006-1012.

17. Santoso AMM, Lutomski JE, Hofman CS, Metzelthin SF, Blom JW, van der Wees PJ, Olde Rikkert MGM, Melis RJF; TOPICS-MDS Consortium. Development of a patientreported outcome measure for geriatric care: The Older Persons and Informal Caregivers Survey Short Form. Value Health 2018;21:1198-1204.

18. Hofman CS, Lutomski JE, Boter H, Buurman BM, de Craen AJ, Donders R, Olde Rikkert MG, Makai P, Melis RJ; TOPICS-MDS research consortium. Examining the construct and known-group validity of a composite endpoint for The Older Persons and Informal Caregivers Survey Minimum Data Set (TOPICS-MDS); A large-scale data sharing initiative. PLoS One 2017;12:e0173081.

19. Higgins JPT, Green S (editors). Cochrane Handbook for Systematic Reviews of Interventions Version 5.1.0 [updated March 2011]. The Cochrane Collaboration, 2011. Accessed 28 July 2018. Available from www.handbook.cochrane.org

20. Downs SH, Black N. The feasibility of creating a checklist for the assessment of the methodological quality both of randomised and non-randomised studies of health care interventions. J Epidemiol Community Health 1998;52:377-384.

21. Deeks JJ. Higgins JPT, Altman DG on behalf of the Cochrane Statistical Methods Group. Chapter 9: Analysing data and undertaking meta-analyses. In: Cochrane Handbook for Systematic Reviews of Interventions. Version 5.1.0 [update March 2011] Ed: Higgins JPT, Green S. The Cochrane Collaboration. Accessed: 02 April 2019. Available at: http://handbook-5-1.cochrane.org/

22. Galvin R, Cusack T, O'Grady E, Murphy TB, Stokes E. Family-mediated exercise intervention (FAME): evaluation of a novel form of exercise delivery after stroke. Stroke 2011;42:681-686.

23. Forster A, Dickerson J, Young J, Patel A, Kalra L, Nixon J, Smithard D, Knapp M, Holloway I, Anwar S, Farrin A; TRACS Trial Collaboration. A structured training programme for caregivers of inpatients after stroke (TRACS): a cluster randomised controlled trial and cost-effectiveness analysis. Lancet 2013;382:2069-2076.

24. Pottie K, Welch V, Morton R, Akl EA, Eslava-Schmalbach JH, Katikireddi V, Singh J, Moja L, Lang E, Magrini N, Thabane L, Stanev R, Matovinovic E, Snellman A, Briel M, Shea B, Tugwell P, Schunemann H, Guyatt G, Alonso-Coello P. GRADE equity guidelines 4: considering health equity in GRADE guideline development: evidence to decision process. J Clin Epidemiol 2017;90:84-91.

25. Gräsel E, Biehler J, Schmidt R, Schupp W. Intensification of the transition between inpatient neurological rehabilitation and home care of stroke patients. Controlled clinical trial with follow-up assessment six months after discharge. Clin Rehabil 2005;19:725-736

26. Ostwald SK, Godwin KM, Cron SG, Kelley CP, Hersch G, Davis S. Home-based psychoeducational and mailed information programs for stroke-caregiving dyads post-discharge: a randomized trial. Disabil Rehabil 2014; 36:55-62. 
27. Perrin PB, Johnston A, Vogel B, Heesacker M, Vega-Trujillo M, Anderson J, Rittman M. A culturally sensitive transition assistance program for stroke caregivers: Examining caregiver mental health and stroke rehabilitation. J Rehabil Res Develop 2010;47:605-615.

28. Shyu Y-L, Kuo L-M, Chen M-C, Chen S-T. A clinical trial of an individualised intervention programme for family caregivers of older stroke victims in Taiwan. J Clin Nurs 2010;19:1675-1685.

29. Toye C, Parsons R, Slatyer S, Aoun SM, Moorin R, Osseiran-Moisson R, Hill KD. Outcomes for family carers of a nurse-delivered hospital discharge intervention for older people (the Further Enabling Care at Home Program): Single blind randomised controlled trial. Int J Nurs Stud 2016;64:32-41.

30. Wang TC, Tsai AC, Wang JY, Lin YT, Lin KL, Chen JJ, Lin BY, Lin TC. Caregiver-mediated intervention can improve physical functional recovery of patients with chronic stroke: a randomized controlled trial. Neurorehabil Neural Repair 2015;29:3-12.

31. Clark MS, Rubenach S, Winsor A. A randomized controlled trial of an education and counselling intervention for families after stroke. Clin Rehabil 2003;17:703-712.

32. Franzen-Dahlin A, Larson J, Murray V, Wredling R, Billing E. A randomized controlled trial evaluating the effect of a support and education programme for spouses of people affected by stroke. Clin Rehabil 2008;22:722-730.

33. Pierce LL, Steiner VL, Khuder SA, Govoni AL, Horn LJ. The effect of a Web-based stroke intervention on carers' well-being and survivors' use of healthcare services. Disabil Rehabil 2009;31:1676-1684.

34. Bakas T, Austin JK, Habermann B, Jessup NM, McLennon SM, Mitchell PH, Morrison G, Yang Z, Stump TE, Weaver MT. Telephone assessment and skill-building kit for stroke caregivers: A randomized controlled clinical trial. Stroke 2015;46:3478-3487.

35. Bishop D, Miller I, Weiner D, Guilmette T, Mukand J, Feldmann E, Keitner G, Springate B. Family Intervention: Telephone Tracking (FITT): a pilot stroke outcome study. Topics Stroke Rehabil 2014;21:S63-S74.

36. Eames S, Hoffmann T, Worrall L, Read S, Wong A. Randomised controlled trial of an education and support package for stroke patients and their carers. BMJ Open 2013;3:e56.

37. Mant J, Winner S, Roche J, Wade DT. Family support for stroke: one year follow up of a randomised controlled trial. J Neurol Neurosurg Psychiatry 2005;76:1006-1008.

38. Cameron JI, Naglie G, Green TL, Gignac MA, Bayley M, Huijbregts M, Silver FL, Czerwonka A. A feasibility and pilot randomized controlled trial of the "Timing it Right Stroke Family Support Program". Clin Rehabil 2015;29:1129-1140.

39. Lindley RI, Anderson CS, Billot L, Forster A, Hackett ML, Harvey LA, and the ATTEND Collaboration Group. Family-led rehabilitation after stroke in India (ATTEND): a randomised controlled trial. Lancet 2017;390:588-599.

40. Grant JS, Elliott TR, Weaver M, Bartolucci AA, Giger JN. Telephone intervention with family caregivers of stroke survivors after rehabilitation. Stroke 2002;33:2060-2065. 
41. Van Den Berg M, Crotty M, Liu E, Killington M, Kwakkel G, Van Wegen E. Early supported discharge by caregiver-mediated exercises and e-health support after stroke: A proof-of-concept trial. Stroke 2016;47:1885-1892.

42. Kalra L, Evans A, Perez I, Melbourn A, Patel A, Knapp M, Donaldson N. Training carers of stroke patients: randomised controlled trial. BMJ 2004;328:1099.

43. Smith J, Forster A, Young J. A randomized trial to evaluate an education programme for patients and carers after stroke. Clin Rehabil 2004;18:726-736.

44. Martinez-Velilla N, Garrues-Irisarri M, Ibanez-Beroiz B, Gil-Cabanas J, Richarte-Garcia A, Idoate-Saralegui F, de Paz PC, Cambra K. An exercise program with patient's involvement and family support can modify the cognitive and affective trajectory of acutely hospitalized older medical patients: a pilot study. Aging Clin Experimental Res 2016;28:483-490.

45. Oupra R, Griffiths R, Pryor J, Mott S. Effectiveness of Supportive Educative Learning programme on the level of strain experienced by caregivers of stroke patients in Thailand. Health Social Care Community 2010;18:10-20.

46. Hawkins RJ, Jowett A, Godfrey M, Mellish K, Young J, Farrin A, Holloway I, Hewison J, Forster A. Poststroke trajectories: the process of recovery over the longer term following stroke. Glob Qual Nurs Res 2017;4:2333393617730209.

47. King RB, Hartke RJ, Houle TT. Patterns of relationships between background characteristics, coping, and stroke caregiver outcomes. Top Stroke Rehabil 2010;17:308-317.

48. Petriwskyj A, Parker D, O'Dwyer S, Moyle W, Nucifora N. Interventions to build resilience in family caregivers of people living with dementia: A comprehensive systematic review. JBI Database Syst Rev Implement Rep 2016;14:238-273.

49. Salpakoski A, Törmäkangas T, Edgren J, Sihvonen S, Pekkonen M, Heinonen A, Pesola $M$, Kallinen $M$, Rantanen $T$, Sipilä $S$. Walking recovery after a hip fracture: a prospective follow-up study among community-dwelling over 60 -year old men and women. Biomed Res Int 2014;2014:289549.

50. Boots LM, de Vugt ME, Kempen GI, Verhey FR. Effectiveness of a blended care selfmanagement program for caregivers of people with early-stage dementia (partner in balance): randomized controlled trial. J Med Internet Res 2018;20:e10017.

51. Duggleby W, Ploeg J, McAiney C, Peacock S, Fisher K, Ghosh S, Markle-Reid M, Swindle J, Williams A, Triscott JA, Forbes D, Jovel Ruiz K. Web-based intervention for family carers of persons with dementia and multiple chronic conditions (my tools 4 care): pragmatic randomized controlled trial. J Med Internet Res 2018;20:e10484.

52. Gitlin LN, Arthur P, Piersol C, Hessels V, Wu SS, Dai Y, Mann WC. Targeting behavioral symptoms and functional decline in dementia: a randomized clinical trial. J Am Geriatr Soc 2018;66:339-345. 
53. Jones CA, Jhangri GS, Feeny DH, Beaupre LA. Cognitive status at hospital admission: postoperative trajectory of functional recovery for hip fracture. J Gerontol A Biol Sci Med Sci 2017;72:61-67.

54. Clarke DJ, Hawkins R, Sadler E, Harding G, McKevitt C, Godfrey M, Dickerson J, Farrin AJ, Kalra L, Smithard D, Forster A. Introducing structured caregiver training in stroke care: Findings from the TRACS process evaluation study. BMJ Open 2014;4: e004473.

55. Larson J, Franzen-Dahlin A, Billing E, Von Arbin M, Murray V, Wredling R. The impact of a nurse-led support and education programme for spouses of stroke patients: A randomized controlled trial. J Clin Nurs 2005;14:995-1003.

56. Pandian JD, Felix C, Kaur P, Sharma D, Julia L, Toor G, Arora R, Gandhi DB, Verma SJ, Anderson CS, Langhorne P, Murthy GV, Hackett ML, Maulik PK, Alim M, Harvey LA, Jan S, Walker M, Forster A, Lindley R. FAmily-Led RehabiliTaTion aftEr Stroke in INDia: the ATTEND pilot study. International Journal of Stroke 2015;10:609-614.

57. Mant J, Carter J, Wade DT, Winner S. Family support for stroke: a randomised controlled trial. Lancet 2000;356:808-813.

58. Shyu YI, Chen MC, Chen ST, Wang HP, Shao JH. A family caregiver-oriented discharge planning program for older stroke patients and their family caregivers. J Clin Nurs 2008;17:2497-508. 


\section{FIGURE AND TABLE LEGENDS}

Table 1: The characteristics of the included studies

Table 2: Summary of meta-analysis results

Figure 1: PRISMA flow chart

Figure 2: Forest-plot to illustrate the standardized mean difference of caregiver interventions compared to usual care on patient health-related quality of life at 3 to 6 month and 12-month follow-up.

Supplementary Figure 1: Funnel plot of patient functional outcomes (3 to 6 month)

Supplementary Table 1: Search strategy performed for EMBASE search database.

Supplementary Table 2: Description of the caregiver training interventions and control interventions prescribed in the included studies

Supplementary Table 3: Results from the assessment of risk of bias

Supplementary Table 4: Results from the Downs and Black appraisal checklist 
Figure 1: PRISMA flow chart
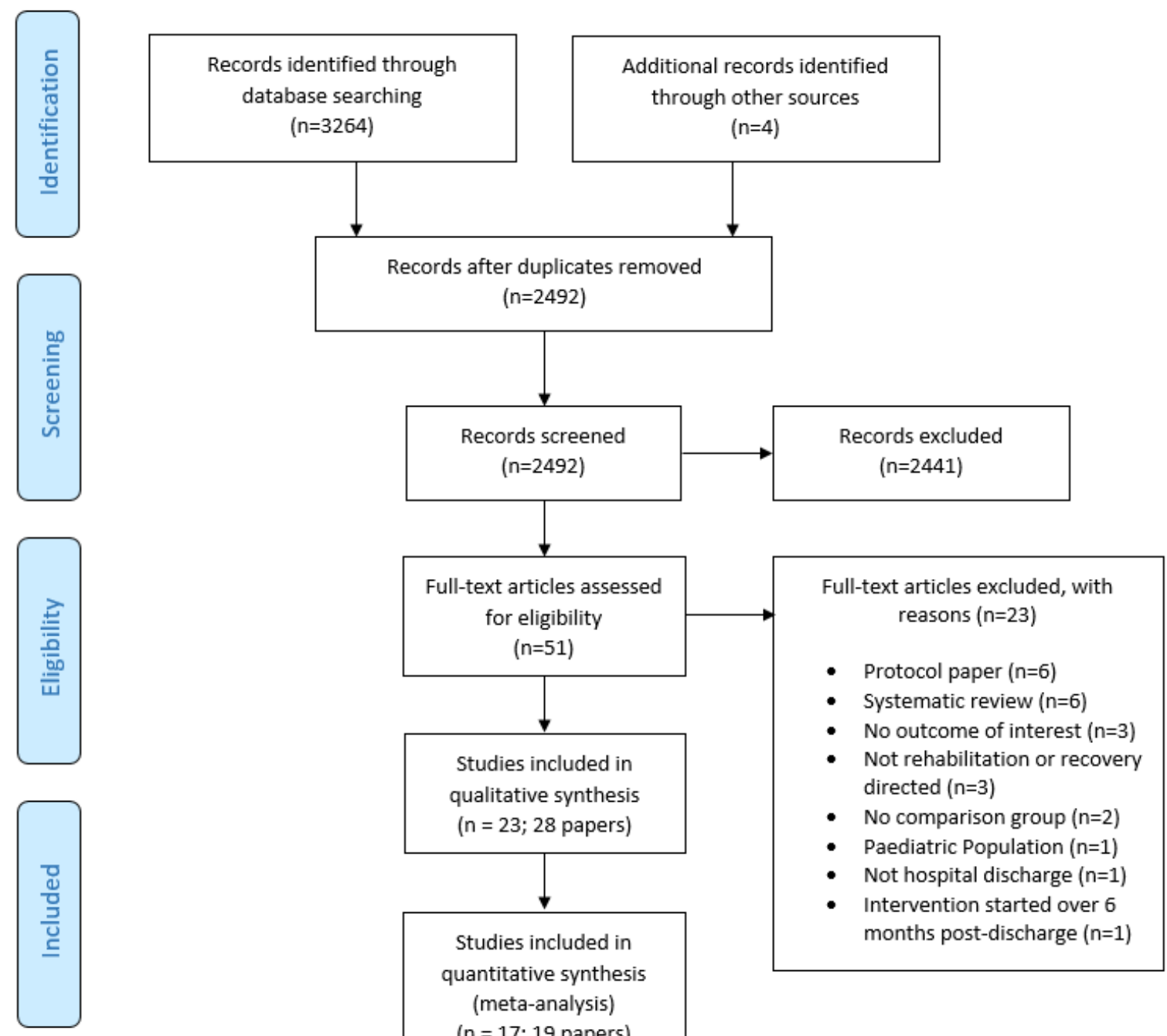

quantitative synthesis

(meta-analysis)

( $n=17 ; 19$ papers) 
Figure 2: Forest-plot to illustrate the standardized mean difference of caregiver interventions compared to usual care on patient health-related quality of life at 3 to 6 month and 12-month follow-up.

$\begin{array}{lcl}\text { Study or Subgroup } & \text { Std. Mean Difference } \\ \mathrm{IV}, \text { Random, } 95 \% \mathrm{Cl}\end{array}$


Table 1: The characteristics of the included studies

\begin{tabular}{|c|c|c|c|c|c|c|}
\hline $\begin{array}{l}\text { Study (country } \\
\text { of origin) }\end{array}$ & Design & $\begin{array}{l}\mathbf{N} \\
\text { (intervention } \\
\text { vs control) }\end{array}$ & $\begin{array}{l}\text { Sex (\% } \\
\text { female) }\end{array}$ & Mean age & $\begin{array}{l}\text { Reason for } \\
\text { Hospital Admission }\end{array}$ & $\begin{array}{l}\text { Mean duration of } \\
\text { hospital admission }\end{array}$ \\
\hline Bakas [34] USA & $\mathrm{RCT}$ & $\begin{array}{l}\text { Overall: } 254 \\
\text { (123 vs } 131) \\
\text { Carer: } 254 \\
\text { (123 vs } 131 \text { ) }\end{array}$ & $\begin{array}{l}50 \% \\
\text { Carer: } 78 \%\end{array}$ & $\begin{array}{l}63 \text { years } \\
\text { Carer: } 54 \text { years }\end{array}$ & Stroke & Not stated \\
\hline $\begin{array}{l}\text { Bishop [35] } \\
\text { USA }\end{array}$ & RCT & 49 (23 vs 26) & $\begin{array}{l}65 \% \\
\text { Carer: } 65 \%\end{array}$ & $\begin{array}{l}70 \text { years } \\
\text { Carer: } 57 \text { years }\end{array}$ & Stroke & Not stated \\
\hline $\begin{array}{l}\text { Cameron [38] } \\
\text { Canada }\end{array}$ & RCT & 31 (21 vs 10$)$ & $\begin{array}{l}\text { Patient: not } \\
\text { stated } \\
\text { Carer: } 77 \%\end{array}$ & $\begin{array}{l}57 \text { years } \\
\text { Carer: not } \\
\text { stated }\end{array}$ & Stroke & Not stated \\
\hline $\begin{array}{l}\text { Clark [31] } \\
\text { Australia }\end{array}$ & RCT & 62 (32 vs. 30) & $\begin{array}{l}39 \% \\
\text { Carer: Not } \\
\text { stated }\end{array}$ & $\begin{array}{l}72 \text { years } \\
\text { Carer: } 70 \text { years }\end{array}$ & Stroke & 27 days \\
\hline $\begin{array}{l}\text { Eames [36] } \\
\text { Australia }\end{array}$ & $\mathrm{RCT}$ & $\begin{array}{l}138 \text { (71 vs } \\
67)\end{array}$ & $\begin{array}{l}54 \% \\
\text { Carer: not } \\
\text { stated }\end{array}$ & $\begin{array}{l}61 \text { years control } \\
55 \text { years } \\
\text { intervention } \\
\text { Carer: not } \\
\text { stated }\end{array}$ & Stroke & Not stated \\
\hline $\begin{array}{l}\text { Forster }[23,54] \\
\text { UK }\end{array}$ & $\mathrm{RCT}$ & $\begin{array}{l}928 \text { (450 vs } \\
478)\end{array}$ & $\begin{array}{l}44 \% \\
\text { Carer: } 68 \% \\
\text { females }\end{array}$ & $\begin{array}{l}71 \text { years } \\
\text { Carer: } 61 \text { years }\end{array}$ & Stroke & 27 days \\
\hline $\begin{array}{l}\text { Franzen-Dahlin } \\
{[32,55] \text { Sweden }}\end{array}$ & RCT & $\begin{array}{l}100 \text { (50 vs } \\
50)\end{array}$ & $\begin{array}{l}80 \% \\
\text { Carer: Not } \\
\text { stated }\end{array}$ & $\begin{array}{l}70 \text { years } \\
\text { Carer: } 67 \text { years }\end{array}$ & Stroke & Not stated \\
\hline $\begin{array}{l}\text { Galvin [22] } \\
\text { Ireland }\end{array}$ & RCT & 40 (20 vs. 20$)$ & $\begin{array}{l}\text { 50\% Carer: } \\
\text { not stated }\end{array}$ & $\begin{array}{l}63 \text { years } \\
\text { intervention; } 70 \\
\text { years control } \\
\text { Carer: not } \\
\text { stated }\end{array}$ & Stroke & $\begin{array}{l}\text { Control: } 40.1 \text { days. } \\
\text { Intervention: } 35.7) \\
\text { days }\end{array}$ \\
\hline Grant [40] USA & $\mathrm{RCT}$ & $\begin{array}{l}74 \text { (groups } \\
\text { not } \\
\text { reported) }\end{array}$ & $\begin{array}{l}53 \% \text { Carer: } \\
91 \%\end{array}$ & $\begin{array}{l}74 \text { years } \\
\text { Carer: } 57 \text { years }\end{array}$ & Stroke & Not stated \\
\hline $\begin{array}{l}\text { Gräsel [25] } \\
\text { Germany }\end{array}$ & $\begin{array}{l}\text { Quasi- } \\
\text { RCT }\end{array}$ & 71 (36 vs 35) & $\begin{array}{l}34 \% \\
\text { Carer: } 74 \%\end{array}$ & $\begin{array}{l}72 \text { years } \\
\text { Carer: } 59 \text { years }\end{array}$ & Stroke & $\begin{array}{l}\text { Intervention: } 64 \\
\text { days } \\
\text { Control: } 53 \text { days }\end{array}$ \\
\hline Kalra [42] UK & RCT & $\begin{array}{l}300 \text { (151 vs } \\
149)\end{array}$ & $\begin{array}{l}\text { Exper:14\% } \\
\text { Cont: } 26 \% \\
\text { Carer: not } \\
\text { stated }\end{array}$ & $\begin{array}{l}76 \text { years } \\
\text { (median) } \\
\text { Carer: not } \\
\text { stated. }\end{array}$ & Stroke & Not stated \\
\hline $\begin{array}{l}\text { Lindley }[[35,56] \\
\text { India }\end{array}$ & RCT & $\begin{array}{l}1250 \text { (623 vs } \\
627)\end{array}$ & $\begin{array}{l}33 \% \\
\text { Carer: not } \\
\text { stated }\end{array}$ & $\begin{array}{l}57.7 \text { years } \\
\text { (mean) } \\
\text { Carer: not } \\
\text { stated }\end{array}$ & Stroke & $\begin{array}{l}\text { Mean length of } \\
\text { stay } \\
\text { Intervention: } 9.3 \\
\text { Control: } 9.5\end{array}$ \\
\hline Mant $[37,57]$ UK & $\mathrm{RCT}$ & $\begin{array}{l}323 \text { (156 vs } \\
167) \\
\text { Carer: } 267 \\
\text { (130 vs 137) } \\
\end{array}$ & $\begin{array}{l}45 \% \\
\text { Carer: } 67 \%\end{array}$ & $\begin{array}{l}73 \text { years } \\
\text { Carer: } 64 \text { years }\end{array}$ & Stroke & Not stated \\
\hline $\begin{array}{l}\text { Martinez-Velilla } \\
\text { [44] Spain }\end{array}$ & $\mathrm{nRCT}$ & 29 (17 vs 12) & $\begin{array}{l}62 \% \text { Carer: } \\
\text { not stated }\end{array}$ & $\begin{array}{l}86.1 \text { years } \\
\text { Carer: not } \\
\text { stated }\end{array}$ & $\begin{array}{l}\text { Acute hospital } \\
\text { admission older } \\
\text { people }\end{array}$ & Not stated \\
\hline
\end{tabular}




\begin{tabular}{|c|c|c|c|c|c|c|}
\hline $\begin{array}{l}\text { Oupra [45] } \\
\text { Thailand }\end{array}$ & $\mathrm{nRCT}$ & $\begin{array}{l}140 \text { (70 vs } \\
70) \\
\text { Carer: } 140 \\
\text { (70 vs } 70) \\
\end{array}$ & $\begin{array}{l}\text { Patient: not } \\
\text { stated } \\
\text { Carer: } 73 \%\end{array}$ & $\begin{array}{l}\text { Patient: not } \\
\text { stated } \\
\text { Carers: } 44 \text { years }\end{array}$ & Stroke & Not stated \\
\hline $\begin{array}{l}\text { Ostwald [26] } \\
\text { USA }\end{array}$ & $\mathrm{RCT}$ & $\begin{array}{l}159 \text { (79 vs } \\
80)\end{array}$ & $\begin{array}{l}25 \% \\
\text { Carer: } 75 \%\end{array}$ & $\begin{array}{l}66 \text { years } \\
\text { Carer: } \\
62.5 \text { years }\end{array}$ & Stroke & Not stated \\
\hline Pierce [33] USA & RCT & 73 (36 vs 37 ) & $\begin{array}{l}\text { Patient: not } \\
\text { stated } \\
\text { Carer: } 75 \%\end{array}$ & $\begin{array}{l}\text { Patient: not } \\
\text { stated } \\
\text { Carer: } 54 \text { years }\end{array}$ & Stroke & Not stated \\
\hline $\begin{array}{l}\text { Perrin [27] } \\
\text { Puerto Rico and } \\
\text { USA }\end{array}$ & RCT & 61 (39 vs 22) & $\begin{array}{l}\text { 95\% Carer: } \\
92 \%\end{array}$ & $\begin{array}{l}69.4 \text { years } \\
\text { Carer: } 58.8 \\
\text { years }\end{array}$ & Stroke & Not stated \\
\hline $\begin{array}{l}\text { Shyu }[28,58] \\
\text { Taiwan }\end{array}$ & RCT & $\begin{array}{l}\text { Patients: } 158 \\
\text { (72 vs } 86 \text { ) }\end{array}$ & $\begin{array}{l}\text { Patients: } \\
43.7 \% \\
\text { Carer: } \\
60.8 \%\end{array}$ & $\begin{array}{l}74.1 \text { years } \\
\text { Carers: } \\
47.9 \text { years }\end{array}$ & Stroke & $\begin{array}{l}17.47 \text { days average } \\
\text { (SD 15.10) }\end{array}$ \\
\hline Smith [43] UK & $\mathrm{RCT}$ & $\begin{array}{l}\text { Patients: } 170 \\
\text { (84 vs } 86 \text { ) } \\
\text { Carers: } 97 \\
\text { (48 vs } 49 \text { ) }\end{array}$ & $\begin{array}{l}\text { Patients: } \\
49 \% \\
\text { Carers: } \\
58 \%\end{array}$ & $\begin{array}{l}74.5 \text { years } \\
\text { (median) } \\
31-92 \text { (range) } \\
\text { Carers: } \\
66 \text { years } \\
\text { (median) } \\
23-85 \text { (range) }\end{array}$ & Stroke & 34.5 days \\
\hline $\begin{array}{l}\text { Toye [29] } \\
\text { Australia }\end{array}$ & $\mathrm{RCT}$ & $\begin{array}{l}141 \text { (62 vs } \\
79)\end{array}$ & $\begin{array}{l}\text { Patient: not } \\
\text { stated } \\
\text { Carer: } \\
74 \%\end{array}$ & $\begin{array}{l}>70 \text { years } \\
\text { Carer: } \\
62 \text { years }\end{array}$ & $\begin{array}{l}\text { Acute hospital } \\
\text { admission older } \\
\text { people }\end{array}$ & Not stated \\
\hline $\begin{array}{l}\text { Van den Berg } \\
\text { [41] USA }\end{array}$ & $\mathrm{RCT}$ & 63 (31 vs 32) & $\begin{array}{l}64 \% \\
\text { Carer: Not } \\
\text { Stated }\end{array}$ & $\begin{array}{l}68.7 \text { years } \\
\text { Carer: not } \\
\text { stated }\end{array}$ & Stroke & Not stated \\
\hline $\begin{array}{l}\text { Wang [30] } \\
\text { Taiwan }\end{array}$ & RCT & 51 (25 vs 26$)$ & $\begin{array}{l}41 \% \\
\text { Carer: not } \\
\text { stated }\end{array}$ & $\begin{array}{l}63.7 \text { years } \\
\text { Carer: not } \\
\text { stated }\end{array}$ & Stroke & Not stated \\
\hline
\end{tabular}

Cont - control; Exper - experimental; $\mathrm{f}$ - female; male - male; $\mathrm{N}$ - number of participants; $\mathrm{nRCT}$ - nonrandomised controlled trial; RCT - randomised controlled trial; SD - standard deviation; UK - United Kingdom; USA - United States of America; vs - versus 
Table 2: Summary of meta-analysis results

\begin{tabular}{|c|c|c|c|c|c|c|c|c|c|}
\hline \multirow[t]{2}{*}{ Outcome } & \multirow{2}{*}{$\begin{array}{c}\text { Time- } \\
\text { Point } \\
\text { (months) }\end{array}$} & \multicolumn{5}{|c|}{ Principal Meta-Analysis } & \multicolumn{3}{|c|}{ Sensitivity Analysis* } \\
\hline & & SMD/MD/RR & Effect & $95 \% \mathrm{Cl}$ & N & $\begin{array}{l}1^{2} \\
(\%)\end{array}$ & SMD/MD/RR & Effect & $95 \% \mathrm{Cl}$ \\
\hline \multirow[t]{2}{*}{ Patient HRQOL } & 3 to 6 & SMD & -0.08 & -0.18 to 0.02 & 1624 & 0 & SMD & -0.05 & -0.16 to 0.05 \\
\hline & 12 & SMD & 0.29 & -0.12 to 0.69 & 500 & 79 & MD & 6.00 & 3.68 to 8.32 \\
\hline \multirow[t]{2}{*}{ Carer HRQOL } & 3 to 6 & SMD & 0.20 & -1.12 to 1.52 & 638 & 98 & SMD & 0.86 & -1.02 to 2.75 \\
\hline & 12 & SMD & 0.46 & -0.34 to 1.27 & 415 & 94 & SMD & 0.46 & -0.34 to 1.27 \\
\hline \multirow[t]{2}{*}{ Caregiver Burden } & 3 to 6 & SMD & -0.33 & -0.71 to 0.04 & 1823 & 94 & SMD & -0.55 & -1.20 to 0.10 \\
\hline & 12 & SMD & -2.21 & -2.51 to -1.92 & 283 & $\mathrm{NE}$ & SMD & -2.21 & -2.51 to -1.92 \\
\hline \multirow[t]{2}{*}{ Patient Function } & 3 to 6 & SMD & 0.00 & -0.08 to 0.08 & 2449 & 46 & SMD & 0.07 & -0.17 to 0.31 \\
\hline & 12 & SMD & -0.02 & -0.17 to 0.13 & 677 & 42 & SMD & -0.06 & -0.25 to 0.12 \\
\hline \multirow[t]{2}{*}{ Patient Anxiety } & 3 to 6 & SMD & -0.69 & -1.79 to 0.41 & 1610 & 99 & SMD & -0.71 & -2.03 to 0.60 \\
\hline & 12 & $\mathrm{MD}$ & -1.75 & -1.89 to -1.61 & 300 & $\mathrm{NE}$ & $\mathrm{MD}$ & -1.75 & -1.89 to -1.61 \\
\hline \multirow[t]{2}{*}{ Patient Depression } & 3 to 6 & SMD & -0.15 & -0.63 to 0.33 & 1682 & 94 & SMD & -0.23 & -0.80 to 0.35 \\
\hline & 12 & SMD & -0.33 & -1.71 to 1.05 & 434 & 98 & SMD & -0.33 & -1.71 to 1.05 \\
\hline \multirow[t]{2}{*}{ Carer Anxiety } & 3 to 6 & $M D$ & 0.10 & -0.32 to 0.52 & 1143 & $\mathrm{NE}$ & MD & 0.10 & -0.32 to 0.52 \\
\hline & 12 & $M D$ & -1.25 & -1.43 to -1.07 & 284 & $\mathrm{NE}$ & MD & -1.25 & -1.43 to -1.07 \\
\hline \multirow[t]{2}{*}{ Carer Depression } & 3 to 6 & SMD & 0.03 & -0.08 to 0.14 & 1239 & 0 & SMD & 0.03 & -0.09 to 0.14 \\
\hline & 12 & SMD & -0.71 & -2.23 to 0.81 & 613 & 99 & SMD & -1.06 & -2.91 to 0.79 \\
\hline \multirow[t]{2}{*}{ Mortality } & 3 to 6 & $\mathrm{RR}$ & 0.84 & 0.65 to 1.09 & 1720 & 0 & RR & 0.84 & 0.65 to 1.09 \\
\hline & 12 & RR & 0.99 & 0.51 to 1.90 & 300 & $\mathrm{NE}$ & RR & 0.99 & 0.51 to 1.90 \\
\hline Rehospitalization & 12 & RR & 1.02 & 0.79 to 1.31 & 1435 & 16 & RR & 1.02 & 0.79 to 1.31 \\
\hline \multirow[t]{2}{*}{ Institutionalisation } & 3 to 6 & $\mathrm{RR}$ & 0.44 & 0.14 to 1.39 & 300 & $\mathrm{NE}$ & RR & 0.44 & 0.14 to 1.39 \\
\hline & 12 & RR & 0.37 & 0.10 to 1.39 & 373 & $\mathrm{NE}$ & RR & 0.33 & 0.07 to 1.60 \\
\hline Hospital Length of Stay & Discharge & $M D$ & -0.22 & -0.97 to 0.53 & 1484 & 20 & $M D$ & -0.22 & -0.97 to 0.53 \\
\hline $\begin{array}{l}\text { Use of out-patient } \\
\text { services }\end{array}$ & 6 & $\mathrm{RR}$ & 1.88 & 1.07 to 3.29 & 187 & 0 & $\mathrm{RR}$ & 2.38 & 0.79 to 7.20 \\
\hline
\end{tabular}

$\mathrm{Cl}$ - confidence interval; HRQOL - health-related quality of life; $\mathrm{I}^{2}$ - inconsistency value; $\mathrm{MD}$ - mean difference; $\mathrm{N}$ - number of participants; $\mathrm{NE}$ - not estimatable as data from single study; RR - risk ratio; SMD - standardised mean difference

* Sensitivity analyses accounting for high risk of bias for detection bias and lack of $a$ priori sample size calculation 
Supplementary Figure 1: Funnel plot of patient functional outcomes ( 3 to 6 month)

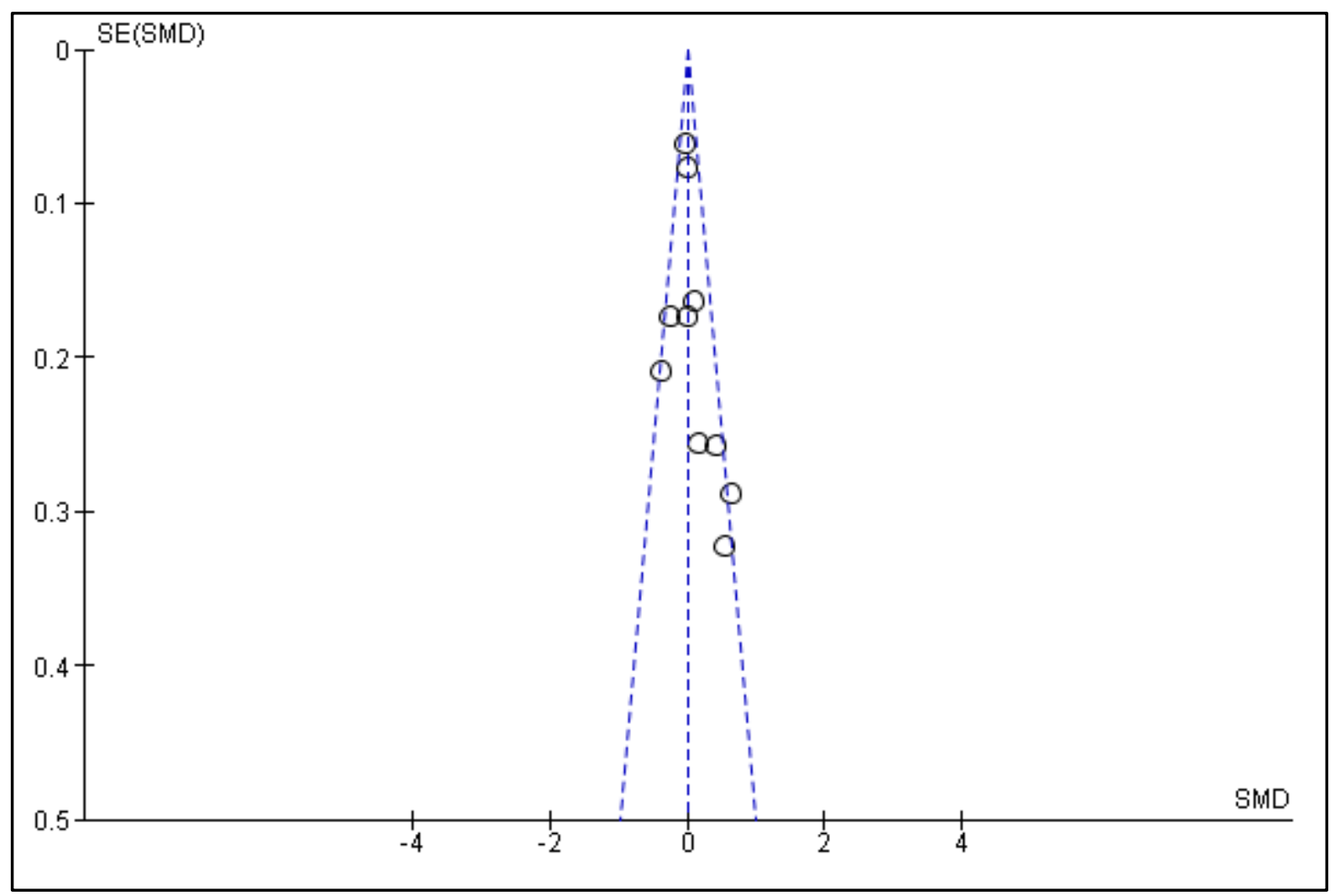

SE - standard error; SMD - standardised mean difference 
Supplementary Table 1: Search strategy performed for EMBASE search database.

1. exp.caregiver/

2. ("informal caregiver" OR spouse or partner or couples OR couple OR "married person" OR "married persons" OR husband OR husbands OR "domestic partner" OR "domestic partners" OR "spousal notification" OR wife OR wives OR "family caregivers" OR "spouse caregiver" OR "spouse caregivers" OR "intimate partner" OR "home care" OR "significant other" OR "close person" OR friend/OR relative/ OR exp parent/ OR family/OR extended family/OR exp family relation/ OR exp nuclear family/ OR volunteer/OR voluntary worker/ OR family centered care/ OR family health/ OR family interaction/ OR family therapy/ OR family life/

3. (carer* OR caregiver* OR care giver* OR care-giver*).tw.

4. next of kin.tw.

5. ((non-professional OR non professional OR informal OR volunteer* OR relative or relatives) adj5 (exercise* OR rehabilitat* OR therap* OR train*)).tw.

6. $\mathrm{OR} / 1-5$

7. training[Title/Abstract])

8. intervention[Title/Abstract])

9. counselling.ti.ab.

10. education.ti.ab.

11. (health education)ti.ab.

12. teaching.ti.ab.

13. manual handling.ti.ab.

14. exercise OR strength* OR rehabilitation OR recovery

15. (walk* OR mobility)ti.ab.

16. ("activities of daily living" OR washing OR dressing OR eating OR social*)

17. OR/7-16

18. (hospital OR inpatient OR "rehabilitation centre" OR institutional* OR medical centre).ti.ab.

19. exp. older people/

20. exp. aged/

21. exp. elderly/

22. old people.ti.ab

23. elder.ti.ab.

24. ("old age" OR "advanced age" OR "frail elderly" OR "frail old" OR "frail older" OR "frail aged").ti.ab 25. OR/19-24

26. 'randomized controlled trial (topic)'/de OR 'randomization'/de OR 'controlled clinical trial (topic)'/de OR 'control group'/de OR 'clinical trial (topic)'/de OR 'double blind procedure'/de OR 'single blind procedure'/de OR 'crossover procedure'/de OR 'experimental therapy'/de OR 'randomized controlled trial'/exp OR 'controlled clinical trial'/de OR 'clinical trial'/de OR random*:ab,ti OR rct:ab,ti OR rcts:ab,ti OR (controlled NEAR/5 (trial* OR stud*)):ab,ti OR (clinical* NEAR/5 trial*):ab,ti OR ((control OR treatment OR experiment* OR intervention) NEAR/5 (group* OR subject* OR patient*)):ab,ti OR (quasi NEXT/1 random*):ab,ti OR (pseudo NEXT/1 random*):ab,ti OR ((control OR experiment* OR conservative) NEAR/5 (treatment OR therapy OR procedure OR manage*)):ab,ti OR ((singl* OR doubl* OR tripl* OR trebl*) NEAR/5 (blind* OR mask*)):ab,ti OR 'cross over':ab,ti OR crossover:ab,ti OR trial:ti OR assign*:ab,ti OR allocate*:ab,ti

27. (non-randomized controlled study.de.) OR (nonrandomly assigned.de.) OR (interrupted time series.de.)

28. OR/28-29

29. AND $/ 6,17,18,19,25,28$ 
Supplementary Table 2: Results from the assessment of risk of bias

\begin{tabular}{|c|c|c|c|c|c|c|c|}
\hline & \multicolumn{2}{|c|}{ Selection Bias } & \multirow{2}{*}{$\begin{array}{c}\text { Performance Bias } \\
\text { Blinding } \\
\text { participants and } \\
\text { personnel }\end{array}$} & \multirow{2}{*}{$\begin{array}{c}\text { Detection Bias } \\
\text { Blinding } \\
\text { outcome } \\
\text { assessment }\end{array}$} & \multirow{2}{*}{$\begin{array}{c}\text { Attrition Bias } \\
\text { Incomplete } \\
\text { outcome data }\end{array}$} & \multirow{2}{*}{$\begin{array}{l}\text { Reporting Bias } \\
\text { Selective } \\
\text { reporting }\end{array}$} & \multirow{2}{*}{$\begin{array}{l}\text { Other Biases } \\
\text { Other sources of bias }\end{array}$} \\
\hline & $\begin{array}{c}\text { Random } \\
\text { sequence } \\
\text { generation }\end{array}$ & $\begin{array}{c}\text { Allocation } \\
\text { concealment }\end{array}$ & & & & & \\
\hline Bakas [34] & $\mathrm{X}$ & Unclear & $\checkmark$ & $\mathrm{X}$ & $\checkmark$ & $\mathrm{X}$ & Baseline imbalance for carers \\
\hline Bishop [35] & $x$ & Unclear & $\checkmark$ & $x$ & $\checkmark$ & $x$ & $\begin{array}{l}\text { Limited reporting of baseline } \\
\text { differences }\end{array}$ \\
\hline Cameron [38] & $x$ & Unclear & $\checkmark$ & Unclear & $\mathrm{X}$ & $x$ & $\begin{array}{l}\text { Adherence and fidelity of the } \\
\text { interventions not controlled }\end{array}$ \\
\hline Clark [31] & $\mathrm{X}$ & $\mathrm{X}$ & $\checkmark$ & $\checkmark$ & $\mathrm{X}$ & $\mathrm{X}$ & No assessment of intervention fidelity \\
\hline Eames [36] & $x$ & $x$ & $\checkmark$ & $x$ & $\checkmark$ & $x$ & $\begin{array}{l}\text { Difference in data collection methods } \\
\text { (telephone \& face to face) }\end{array}$ \\
\hline Forster $[23,54]$ & $\mathrm{X}$ & $\mathrm{X}$ & $\checkmark$ & $\checkmark$ & $\mathrm{X}$ & $\mathrm{X}$ & None \\
\hline Franzen-Dahlin $[32,55]$ & $x$ & $\mathrm{X}$ & $\checkmark$ & $\checkmark$ & $\checkmark$ & $\mathrm{x}$ & Co-interventions not assessed \\
\hline Galvin [20] & $x$ & Unclear & $\checkmark$ & $x$ & $\checkmark$ & $x$ & $\begin{array}{l}\text { Baseline imbalance for age and greater } \\
\text { impairment in FAME group }\end{array}$ \\
\hline Grant [40] & $x$ & $\mathrm{X}$ & $\mathrm{X}$ & $x$ & $\mathrm{X}$ & Unclear & None \\
\hline Gräsel [25] & $\checkmark$ & $\checkmark$ & $\checkmark$ & $\checkmark$ & $\checkmark$ & $x$ & Power insufficient \\
\hline Kalra [42] & $x$ & $\mathrm{X}$ & $\checkmark$ & $x$ & $\mathrm{X}$ & $x$ & None \\
\hline Lindley $[39,56]$ & $\mathrm{X}$ & $x$ & $\checkmark$ & $\mathrm{X}$ & $\mathrm{X}$ & $\mathrm{X}$ & None \\
\hline Mant $[37,57]$ & $x$ & $x$ & $\checkmark$ & $x$ & $x$ & $\mathrm{X}$ & Baseline imbalance evident \\
\hline Ostwald [26] & $x$ & $\checkmark$ & $\checkmark$ & $x$ & $\checkmark$ & $x$ & $\begin{array}{l}\text { Imbalance in lost to follow-up where } \\
\text { different characteristics }\end{array}$ \\
\hline Pierce [33] & $x$ & Unclear & $\checkmark$ & $\checkmark$ & $\checkmark$ & $\checkmark$ & No access of contamination \\
\hline Perrin [27] & $x$ & $\checkmark$ & $\checkmark$ & $\checkmark$ & $\checkmark$ & $\checkmark$ & $\begin{array}{l}\text { Limited information on intervention as } \\
\text { in who delivered it and practical } \\
\text { considerations. }\end{array}$ \\
\hline Shyu $[28,58]$ & $\mathrm{X}$ & $\checkmark$ & $\checkmark$ & $\checkmark$ & $\checkmark$ & $\mathrm{X}$ & Size of cluster for trial power not clear \\
\hline Smith [28] & $\mathrm{X}$ & $\mathrm{X}$ & $\checkmark$ & $x$ & $\mathrm{X}$ & $\mathrm{X}$ & None \\
\hline Toye [29] & $\mathrm{X}$ & $\checkmark$ & $\checkmark$ & $\mathrm{X}$ & $\mathrm{X}$ & $\mathrm{X}$ & None \\
\hline Van den Berg [41] & $x$ & $\mathrm{X}$ & $\checkmark$ & $x$ & $\mathrm{X}$ & $\mathrm{x}$ & None \\
\hline Wang [30] & $x$ & $\checkmark$ & $\checkmark$ & $x$ & $\checkmark$ & $\mathrm{X}$ & None \\
\hline
\end{tabular}

$\checkmark$ - bias evident; $X$ - no bias evident; Unclear - no evidence to determine if the case 
Supplementary Table 3: Results from the Downs and Black appraisal checklist

\begin{tabular}{|c|c|c|}
\hline & $\begin{array}{l}\text { Martinez- } \\
\text { Velilla [44] }\end{array}$ & $\begin{array}{c}\text { Oupra } \\
{[45]}\end{array}$ \\
\hline \multicolumn{3}{|l|}{ Reporting } \\
\hline Are aims/objectives clearly stated & $\bar{\checkmark}$ & $\bar{\checkmark}$ \\
\hline Are main outcomes clearly described & $\checkmark$ & $\checkmark$ \\
\hline Are participant characteristics clearly described & $\checkmark$ & $\checkmark$ \\
\hline Are the interventions clearly described & $\checkmark$ & $\checkmark$ \\
\hline Are distributions of principal confounded clearly described & $\mathrm{X}$ & $\mathrm{X}$ \\
\hline Are the main findings clearly described & $\checkmark$ & $\checkmark$ \\
\hline Is there an estimate of variability for main outcomes & $\checkmark$ & $\checkmark$ \\
\hline Have all potentially important adverse events been reported & $\checkmark$ & $\mathrm{X}$ \\
\hline Are participants lost to follow-up clearly described & $\checkmark$ & $\checkmark$ \\
\hline Have actual $p$-values been reported & $\checkmark$ & $\checkmark$ \\
\hline \multicolumn{3}{|l|}{ External Validity } \\
\hline Are participants approached representative of normal population. & $\checkmark$ & $\checkmark$ \\
\hline Are participants recruited representative of normal population. & $\checkmark$ & $\checkmark$ \\
\hline Were staff and the environment study was conducted typical of real life. & $\checkmark$ & $\checkmark$ \\
\hline \multicolumn{3}{|l|}{ Internal Validity - Bias } \\
\hline Were participants blinded to intervention & $\mathrm{X}$ & $\mathrm{X}$ \\
\hline Were measurers blinded to intervention & $\checkmark$ & $\mathrm{X}$ \\
\hline Was there data dredging & $\mathrm{X}$ & $\mathrm{X}$ \\
\hline Were analyses adjusted for different lengths of follow-up & $\mathrm{X}$ & $\mathrm{X}$ \\
\hline Were statistical tests used appropriately to assess main outcomes & $\checkmark$ & $\checkmark$ \\
\hline Was compliance to intervention assessed & $\mathrm{X}$ & $\mathrm{X}$ \\
\hline Were main outcome measures reliable and valid & $\checkmark$ & $\checkmark$ \\
\hline \multicolumn{3}{|l|}{ Internal Validity - Confounding (Selection bias) } \\
\hline Were participants in each intervention group recruited from same population & $\checkmark$ & $\checkmark$ \\
\hline Were participants different between the intervention groups & $\checkmark$ & $\checkmark$ \\
\hline Was randomisation performed to allocate intervention & $\mathrm{X}$ & $\mathrm{X}$ \\
\hline Was randomisation concealed & $\mathrm{X}$ & $\mathrm{X}$ \\
\hline Was their adjustment between the groups for confounding & $\mathrm{X}$ & $\mathrm{X}$ \\
\hline Were lost to follow-up taken into account between groups. & $\mathrm{X}$ & $\mathrm{X}$ \\
\hline \multicolumn{3}{|l|}{ Power } \\
\hline Did the study have sufficient power & $x$ & $x$ \\
\hline
\end{tabular}

$\checkmark$ - no bias evident; $X$ - bias evident; 
Supplementary Table 4: Description of the caregiver training interventions and control interventions prescribed in the included studies

\begin{tabular}{|c|c|c|}
\hline Study & Intervention & Control \\
\hline Bakas [34] & $\begin{array}{l}\text { Within } 8 \text { weeks of discharge: manual (info on findings information on stroke; managing survivors emotions and } \\
\text { behaviours providing physical care; providing instrumental care; dealing with personal responses to providing } \\
\text { care and tips on care around depression, expectation management; communication with health workers; problem } \\
\text { solving; stress management) plus 8-weekly telephone sessions (focussed on identifying and prioritising needs and } \\
\text { concerns and using the manual to overcome these and skill-building strategies). Calls made by nurse with booster } \\
\text { at } 12 \text { weeks. }\end{array}$ & $\begin{array}{l}\text { American Stroke Association (AHA) } \\
\text { pamphlet and } 8 \text { weekly calls with } 12 \text { week } \\
\text { booster only to active listening strategies } \\
\text { and to get additional information from ASA } \\
\text { and health providers. }\end{array}$ \\
\hline Bishop [35 & $\begin{array}{l}\text { FITT intervention designed to identify problems during the transition to home discharge to explore issues around: } \\
\text { family functioning, mood, neurocognitive function, functional independence and physical health. They were } \\
\text { aimed at improving problem-solving skills and provide follow-up support. Intervention delivered via telephone } \\
\text { calls led by an individual trained in the FITT approach. Supplemented with written material on general stroke } \\
\text { health. Intervention started on hospital discharge during the initial } 6 \text { months after discharge. Frequency was } \\
\text { weekly calls for the first } 6 \text { weeks, biweekly next } 2 \text { months, month following } 2 \text { months. } 13 \text { calls to each individual } \\
\text { ( } 26 \text { calls per dyad). }\end{array}$ & $\begin{array}{l}\text { Did not receive the experimental } \\
\text { intervention. Usual care. }\end{array}$ \\
\hline $\begin{array}{l}\text { Cameron } \\
{[35]}\end{array}$ & $\begin{array}{l}\text { Face-to-face meeting prior to discharge followed by after discharge telephone calls for } 6 \text { months after discharge. } \\
\text { Support to explain current needs and strategies to assist in the care of individuals following stroke. Supported by } \\
\text { a guidebook guiding recovery. The 'self-directed' version provided a face-to-face contact without the telephone } \\
\text { consultations. }\end{array}$ & $\begin{array}{l}\text { Did not receive the experimental } \\
\text { intervention. Usual care. }\end{array}$ \\
\hline Clark [31] & $\begin{array}{l}\text { On hospital discharge, carers and patients received a stroke information package PLUS } 3 \text { visits from a social } \\
\text { worker trained in counselling. Manual provides advice on what a stroke is, how to avoid another, consequences } \\
\text { and coping suggestions and information on surrounding services. Each social worker visit was } 1 \text { hour, and } \\
\text { discussed the information provided in the manual. Visit } 1 \text { was within } 3 \text { weeks of discharge, visit } 2 \text { at } 2 \text { months, } \\
\text { visit } 3 \text { and } 5 \text { months. These were counselling sessions re-enforcing manual information. }\end{array}$ & $\begin{array}{l}\text { Did not receive the experimental } \\
\text { intervention. Usual care. }\end{array}$ \\
\hline Eames [36] & $\begin{array}{l}\text { Computer generated, tailored written information booklet and verbal reinforcements prior to (up to } 3 \text { times) and } \\
\text { for } 3 \text { months after discharge (up to } 3 \text { times). Information tailored to need but generally on (assessing knowledge, } \\
\text { exploring barriers and problem solving, correcting misinformation; providing specific an personalised information } \\
\text { on risks and seriousness of unhealthy behaviours benefits of healthy behaviours proving reassurance and } \\
\text { encouraging support networks, using persuasion and training to pace activities; stress management strategies. } \\
\text { Intervention was delivered by an occupational therapist but it was designed to be delivered by any health } \\
\text { professional who has knowledge and experience in stroke care. }\end{array}$ & $\begin{array}{l}\text { Did not receive the experimental } \\
\text { intervention. Usual care. }\end{array}$ \\
\hline $\begin{array}{l}\text { Forster } \\
{[23,54]}\end{array}$ & $\begin{array}{l}\text { Structured training programme (London Stroke Carer Training Course) for caregivers including assessment of } \\
\text { competencies in knowledge and skills required to manage disabled stroke survivors. Intervention was taught by a } \\
\text { multidisciplinary team. This was formally assessed with carers 'signed-off' as competent. This included observing } \\
\text { skills e.g. manual assistance of individuals in transfers and questioning understanding. This was individually }\end{array}$ & $\begin{array}{l}\text { Did not receive the experimental } \\
\text { intervention. Usual care. }\end{array}$ \\
\hline
\end{tabular}




\begin{tabular}{|c|c|c|}
\hline & $\begin{array}{l}\text { delivered to participants prior to hospital discharge and supplemented with a stroke information package PLUS } \\
\text { one visit or telephone call delivered by a health professional trained in the intervention to reinforce learning. } \\
\text { Manual provides advice on what a stroke is, how to avoid another, consequences and coping suggestions and } \\
\text { information on surrounding services. The visit or telephone call was up to } 1 \text { hour, and discussed the information } \\
\text { provided in the manual. }\end{array}$ & \\
\hline $\begin{array}{l}\text { Franzen- } \\
\text { Dahlin } \\
{[32,55]}\end{array}$ & $\begin{array}{l}6 \text { group meetings over } 6 \text { months plus booster meeting at } 12 \text { months. Groups consisted of } 10 \text { people per group } \\
\text { with same members, led by } 2 \text { stroke specialist nurses. Topics discussed: symptoms and occurrence of stroke, risk } \\
\text { factors, treatment, prevention, personality changes, and social aspects. Sessions started with a lecturer to } \\
\text { increase knowledge. Open sessions also available during in-patients. }\end{array}$ & $\begin{array}{l}\text { Did not receive the experimental } \\
\text { intervention. Usual care. }\end{array}$ \\
\hline Galvin [20] & $\begin{array}{l}\text { FAME intervention provided which was a } 35 \text {-minute daily bedside exercise intervention which was assisted by a } \\
\text { carer delivered at home or in the hospital. Family member provided with skills to provide this. Goal setting } \\
\text { individuals exercises provided with weekly feedback by a physiotherapist. Aims was achiever stability and improve } \\
\text { gait velocity and lower limb strength. }\end{array}$ & $\begin{array}{l}\text { Did not receive the experimental } \\
\text { intervention. Usual care. }\end{array}$ \\
\hline Grant [40] & $\begin{array}{l}\text { Social problem-solving skills were taught to caregivers by trained nurses over an initial 3-hour face-to-face session } \\
\text { at home. The intervention was to encourage the adoption of a positive problem-solving. This was delivered by } \\
\text { working on } 3 \text { case-examples during the initial tutorial. This was developed with weekly sessions on Weeks } 2,3 \\
\text { and } 4 \text { after discharge and then biweekly on weeks } 6,8,10 \text { and } 12 \text { post discharge via telephone contact. Provision } \\
\text { of reading material published by the American Heart Association and National Stroke Association was also } \\
\text { provided. }\end{array}$ & $\begin{array}{l}\text { Did not receive the experimental } \\
\text { intervention. Usual care. }\end{array}$ \\
\hline Gräsel [25] & $\begin{array}{l}\text { Experimental intervention was usual care PLUS psycho-educational seminar for patient and carer with } \\
\text { information on expectations, caregiving at home, sources of assistance (provided within a hospital setting); } 3 \\
\text { sessions on individual training led by a nurse with the carer and patients to provide whilst an inpatient, advice on } \\
\text { carers and skills to care; therapeutic weekend care which is a weekend before discharge to practice skills; 3- } \\
\text { months after discharge, telephone counselling provided. }\end{array}$ & $\begin{array}{l}\text { Did not receive the experimental } \\
\text { intervention. Usual care. }\end{array}$ \\
\hline Kalra [42] & $\begin{array}{l}\text { Provision of basic nursing and facilitation of personal care techniques. In addition to the control intervention this } \\
\text { included instructions on common stroke-related problems and prevention of these problems e.g. bed sores, } \\
\text { continence, nutrition, positioning gait facilitation and use of local services; hands-on training on manual handling, } \\
\text { mobility, transfers, continence and assistance of ADLs and communication tailored to individual patient needs. } \\
\text { This consisted of } 3-4 \text { sessions for } 30-45 \text { minutes depending on need. Assessment of caregiver competencies was } \\
\text { made. One follow-through home visit was made to adopt skills learnt into a home environment. }\end{array}$ & $\begin{array}{l}\text { Did not receive the experimental } \\
\text { intervention. Usual care. }\end{array}$ \\
\hline $\begin{array}{l}\text { Lindley } \\
{[39,56]}\end{array}$ & $\begin{array}{l}\text { Intervention delivered by a rehabilitation professional as an inpatient and continued at home. Family member } \\
\text { was trained to provide simplified evidence-based rehabilitation including assessing for disability, they were } \\
\text { provided information, goal setting advice for basic ADLs and extended ADLs and communication skills; given } \\
\text { caregiver training for limb positioning, encouragement on task-specific activities and preparation for hospital } \\
\text { discharge. Taught } 1 \text { hour a day for } 3 \text { days in hospital and then up to } 6 \text { home visits to assess progress, continue }\end{array}$ & $\begin{array}{l}\text { Did not receive the experimental } \\
\text { intervention. Usual care. }\end{array}$ \\
\hline
\end{tabular}


\begin{tabular}{l|l}
\hline & training, reset goals and further support by telephone up to 3 months after randomisation. Manual provided at
\end{tabular} the first home visits.

Mant $\quad$ Family support within 6 weeks following a stroke. The Stroke Family Support Organisers (SFSO) determined the

$[37,57] \quad$ frequency and nature of the visits and contact. They provided information about stroke and recovery as well as providing Stroke Association information leaflets.

Martinez- $\quad$ An individualised graduated exercise program prescribed and supervised by an exercise physiologist and the unit Velilla [44] physiotherapist along with education of ward and team staff, patients and caregivers to actively encourage mobility and functional independence. The exercise program was adapted to clinical and cognitive and it was established that participants should exercise 30-40 min 3 times daily to cover at least $600 \mathrm{METS} /$ week of moderate-vigorous intensity physical activity. During the discharge period and for 1 month later, participants continued performing the exercise program and they registered the activity on a monthly calendar that was reviewed during the medical visit. The exercise programme was supported with an exercise booklet.

Oupra [45] $\quad$ The SELF-program comprising didactic education sessions, hands-on training for family caregivers, a booklet for family caregivers describing stroke care and three follow-up phone calls. An appointment was made with family caregivers in the intervention group to attend three interactive group sessions lasting approximately 120- to 150min duration including time for group discussion. Sessions were provided in a hospital-ward meeting room. Family caregivers practiced with their relatives under the supervision of the nurse researcher and two research assistants. The first session focused on the causes and risk factors of stroke, the associated complications and methods to prevent or reduce the severity of complications. The second session covered swallowing difficulties and feeding, and maintaining adequate hydration and nutrition. The final session included urinary catheter care, preventing urinary tract infections, techniques for bladder and bowel training, positioning, mobility and transfer, the role of the family caregiver and caring for themselves. Family caregivers were supervised practicing activities such as adjusting the patient's position to prevent pressure ulcers, feeding, catheter care, lifting and handling technique, and mobility and transfer with the stroke survivors. Each family caregiver was given written information on the content covered in the form of a booklet. After discharge, the caregivers in the intervention group were telephoned on an agreed day and time during the third week of each month, for 3 months. Dyads in the home-based intervention received home visits for the first 6 months after discharge by advance practice nurses, occupational and physical therapists, who provided information following pre-determined protocols, developed to provide education, support, skill training, counselling and linkages to social and community resources. Average 16 visits in total with each 70 minutes long.

Pierce [33] Web-based education programme within formation on stroke and caring; carer need information; email forum with a nurse specialist and rehabilitation team members (therapist, pharmacist, dietician, social worker and physician), and non-structured email discussing amongst participants facilitated by a nurse. Hard and software provided to participants randomised to the intervention group to access the internet to participate in this study. Web provided for the initial 12 months following hospital discharge.
Did not receive the experimental

intervention. Usual care.

Did not receive the experimental intervention. Usual care.

Did not receive the experimental intervention. Usual care.

Dyads (stroke survivors and their spouse) received mailed information for 12 months.

Did not receive the experimental intervention. Usual care.

No provision of computer access and advised not to access the internet. 
Perrin [27]

Provision of the 'Guidebook for Caregivers of Veterans Post Stroke (English and Spanish versions) providing information on stroke pathology, recognition of stroke and TIA and preventative strategies; advice to stroke caregivers on how to provide care to stroke survivors; recovery experiences and comment expectations and experiences such as disability, disruption in sense of self, social isolation and depression. This was provided with a video telephone intervention provided just prior to discharge from hospital to home, provided Week 1, 2, 4 and 6 which provides individual support to supplement the guidebook.

Shyu

Inpatient health education and referral services as well as after discharge telephone follow-ups and home visits.

The discharge needs of caregivers were initially assessed within 48 hours of admitting their older stroke patient to the hospital and again before discharge. The results of this assessment were used to guide individualised interventions for caregivers. After the initial needs assessment, the research nurses visited the patient and caregiver at the bedside, four to five times. Each visit was approximately 30 minutes, based on the patient's needs during hospitalisation. The research nurse provided individualised health information in preparation for discharge, both oral and written instructions and demonstrated specific caregiving skills, such as dressing and transferring, if needed. If the caregiver needed after discharge health care support, a support or social services group, the research nurse would make the discharge referrals based on the specific needs of that caregiver patient dyad. A research nurse met the caregiver before discharge and used the Competing Needs Checklist to help identify potential competing needs at home. In addition to providing health education based on the assessment of caregiver needs during the patients' hospitalisation, research nurses improved caregiver preparation by initiating a telephone consultation within the first week after discharge. This telephone consultation which followed a structured guide and lasted 30-45 minutes was designed to find out how the actual caregiving was progressing and to answer any questions of the caregiver. Research nurses also made two home visits, ranging from 30-60 minutes, one within the first week and one at the end of the first month after discharge. During these visits, the nurses observed the actual caregiving, answered questions, demonstrated skills and looked for any potential problems. Health care teaching in the home setting was usually provided to family caregivers in the presence of older stroke survivors.

Smith [28] $\quad$ Patients and carers were given a copy of the Stroke Recovery Programme manual and invited to attend meetings with members of their multidisciplinary team. The manual contains information about the causation and consequences of stroke, stroke recovery, financial benefits, and relevant services and has a specific section for carers. The Stroke Recovery Programme manual was supported by pre-arranged review meetings every two weeks with their multidisciplinary team (doctor, nurse, physiotherapist and occupational therapist) lasting 20 minutes.

The intention of the meeting (provided in a hospital dayroom) was to provide background information about stroke, discuss patient's progress, answer specific questions and develop shared rehabilitation goals. Patients or carers allocated to the intervention group but unable to attend a meeting due to early discharge were invited to meet with the consultant in the outpatients clinic.
Did not receive the experimental

intervention. Usual care.

\section{Did not receive the experimental}

intervention. Usual care.

Did not receive the experimental

intervention. Usual care. 


\begin{tabular}{|c|c|c|}
\hline Toye [29] & $\begin{array}{l}\text { Further Enabling Care at Home program. Involving a strict telephone protocol by the specially trained nurse, using } \\
\text { the Carer Support Needs Assessment Tool, which has fourteen items covering: (a) support that enables the } \\
\text { caregiver to care for the patient at home, and (b) support for the caregiver in their caring role. There were three, } \\
\text { sequential, telephone contacts ( } 1 \text { week, 7-10 days and } 14 \text { days post discharge). }\end{array}$ & $\begin{array}{l}\text { Providing a copy of the letter from the } \\
\text { hospital doctor to the patient's regular } \\
\text { medical practitioner plus any required } \\
\text { medications, prescriptions, referrals, or } \\
\text { outpatient appointments. 'At risk' patients } \\
\text { and/or caregivers, as prioritised by the } \\
\text { social work team at that team's discretion, } \\
\text { received whatever social work services } \\
\text { were deemed to be appropriate based upon } \\
\text { the issues presented. }\end{array}$ \\
\hline $\begin{array}{l}\text { Van den } \\
\text { Berg [41] }\end{array}$ & $\begin{array}{l}\text { 8-week caregiver mediated training program with support using a customized exercise app loaded onto a tablet. } \\
\text { While in hospital, the patient and carer were provided with an iPad which was loaded with the training } \\
\text { application with } 37 \text { standardized exercises aimed to improve gait and gait-related mobility, such as standing, } \\
\text { turning, or making transfers. The patient and their caregiver were asked to perform a selective set of exercises for } \\
8 \text { weeks, at least } 5 \text { times a week for } 30 \text { minutes, and had a weekly evaluation session with the physiotherapist. If } \\
\text { discharge occurred earlier than the end date of the intervention period, the program continued at home with } \\
\text { ongoing use of the exercise app, tele-rehabilitation services and weekly home visits ( } 8 \text { in total). Participants in the } \\
\text { intervention group wore an activity monitor for the } 8 \text {-week intervention period. }\end{array}$ & $\begin{array}{l}\text { Did not receive the experimental } \\
\text { intervention. Usual care. }\end{array}$ \\
\hline Wang [30] & $\begin{array}{l}\text { A physical therapist outlined a personalized weekly training schedule for each patient according to the program. } \\
\text { The program was roughly divided into } 3 \text { phases: phase } 1 \text { (weeks 1-4), to improve patients' body functions and } \\
\text { structural components; phase } 2 \text { (weeks 5-8), to improve patients' ability to undertake everyday activities within } \\
\text { their living environments using task-specific restorative and compensatory training methods; and phase } 3 \text { (weeks } \\
\text { 9-12), to help the patients reintegrate into the society by participating in restorative outdoor leisure activities. } \\
\text { Physical therapist visited once weekly for approximately } 90 \text { minutes over } 12 \text { weeks to teach patients personalized } \\
\text { rehabilitation skills and to teach the caregivers the skills necessary to assist the patients in performing the } \\
\text { planned tasks during trial period. }\end{array}$ & $\begin{array}{l}\text { Did not receive the experimental } \\
\text { intervention. Usual care. }\end{array}$ \\
\hline
\end{tabular}

ADLs - activities of daily living; METs - metabolic equivalent of task value; TIA - transient ischaemic attack 